\title{
Demokratie, Armut und Entwicklung: Ein Überblick ${ }^{1}$
}

\author{
Von Jürgen $H$. Wolff
}

\section{Einleitung}

Nicht nur der Mann auf der Straße, auch ein erheblicher Teil der Wissenschaftler glaubt zu wissen, Demokratie habe Wohlstand zur notwendigen, wenngleich nicht hinreichenden Voraussetzung. Insbesondere ältere Modernisierungstheorien spekulieren über Zusammenhänge, ja Ursache-Wirkungsbeziehungen zwischen wirtschaftlicher, gesellschaftlicher und politischer Entwicklung, meist im Sinne einer gelegentlich krisenhaften, aber alles in allem doch unilinearen Entwicklung hin zum eigenen Vorbild, das fraglos die Krone des Universums abgab.2 Eine ernsthafte Auseinandersetzung mit den (freilich wenigen) Beispielen armer, aber (relativ) demokratischer Länder unterblieb im allgemeinen ebenso wie eine solche mit der Tradition hochentwickelter, jedoch totalitärer Systeme im alten Ostblock. Umgekehrt haben zahlreiche Zusammenbrüche demokratischer Systeme inzwischen den Glauben an eine immer weiter voranschreitende Demokratisierung in Ländern der Dritten Welt parallel zu deren Wirtschaftsentwicklung verringert. Es erscheint angebracht, die Frage nach dem Zusammenhang von Demokratie und Wirtschaft systematisch zu untersuchen und Folgerungen für die Außenpolitik von demokratischen Industrieländern zu ziehen.

Wir versuchen im folgenden, den Forschungsstand kritisch zu referieren. Dabei geht es uns nicht (im Sinne der in anderem Zusammenhang einmal so benannten "Plädoyertechnik") darum, Beispiele und Gegenbeispiele vorzustellen3, sondern nach systematischen Zusammenhängen zu fragen. Solche können, der Natur der Sache nach, nur durch die stringente Untersuchung einer möglichst großen Zahl von Fällen ermittelt werden. Statistische Analysen sind daher unvermeidlich, und in der Tat wendet die jüngere Forschung vorwiegend solche Methoden an. Statistische Untersuchungen können grundsätzlich als Zeitpunkt- und als Zeitreihenkorrelation angelegt sein, womit die beiden Hauptkapitel des Aufsatzes bezeichnet wären. $\mathrm{Zu}$ verbinden sind sie durch eine methodische Reflexion darüber, ob der einen oder anderen Methode der Vorzug gegeben werden muß. Schließlich wäre zu unter-

1 Überarbeitete Fassung eines Vortrages vor dem Arbeitskreis "Dritte-Welt-Politik" beim Auswärtigen Amt am 12. November 1990 in Bonn.

2 Ein früher Vorläufer ist in der Vorrede des "Kapitals" von Karl Marx zu finden, wo die Industrieländer als Zukunft der unterentwickelten Länder hingestellt werden.

3 Das Ergebnis wäre vermutlich, da $\beta$ jeder Fall einzigartige historische Bedingungen autweist und daher unvergleichlich ist! 
suchen, ob nicht die häufig vermutete Kausalitätsrichtung umzudrehen wäre: Statt Wohlstand als Voraussetzung für Demokratie zu begreifen, könnte er deren Folge sein.

Die hochinteressante verwandte Frage nach dem Zusammenhang von Demokratie und Einkommensverteilung (nicht absolutem Wohlstand) eines Landes kann aus Raumgründen nur in einer Fußnote gestreift werden.

\section{Die klassische Analyse: Zeitpunktkorrelationen Demokratie - Wohlstand}

Das Ergebnis ist eindeutig: Bei einer simplen Zeitpunktanalyse korrelieren Indikatoren für Demokratie und für Wohlstand/Armut hoch miteinander: Reiche Nationen tendieren zu demokratischer, arme zu nichtdemokratischer Verfassung.

Dazu einige Autoren und Zitate: Max Weber4: Moderne Demokratie in reinster Ausprägung kann nur unter kapitalistischer Industrialisierung vorkommen. Seymour Martin Lipset 5 faßt "wirtschaftliche Entwicklung" weit (Reichtum, Industrialisierung, Urbanisierung und Erziehung) und schließt: "In each case, the average wealth ... is much higher for the more democratic countries" 6 oder auch "increased wealth is ... related causally to the development of democracy".7 Oder er verweist zustimmend auf Max Weber8: "the basic argument runs that capitalist economic development (facilitated and most developed in Protestant areas) created the burgher class whose existence was both a catalyst and a necessary condition for democracy".9 Almond and Coleman 10 kommen unter Einschränkungen (die sich auf Unterschiede zwischen den Entwicklungsregionen und auf eklatant abweichende Einzelfälle beziehen) doch grosso modo zu einer Bestätigung ihrer "Arbeitshypothese" "that there is a positive correlation between economic development and political competetiveness".11 Cutright 12 vermerkt: "The level of political development is highly

4 M. Weber, Zur Lage der bürgerlichen Demokratie in Rußland, in: Archiv für Sozialwissenschaft und Sozialpolitik, 22/1906, S. 234-355; hier: S. 346 ff.

5 In einem Aufsatz mit dem bezeichnenden Titel "Some Social Requisites of Democracy: Economic Development and Political Legitimacy" (mit anderen Worten: Wirtschaftliche Entwicklung ist eine notwendige, aber nicht hinreichende Bedingung für Demokratie!), in: The American Political Science Review, 1/1959, S. 69-105; hier: S. 75 ff.

6 S.M.Lipset, Anm. 5, S. 75.

7 S.M.Lipset, Anm. 5, S. 83.

8 S.M. Lipset, Anm. 5, S. 85.

9 Lipset nimmt diese Gedanken teils wörtlich in seinem "Political Man" von 1960 wieder auf (im Kap. II, Economic Development and Democracy), London: 1960.

10 G.A.Almond/J.S. Coleman (Hrsg.), The Politics of the Developing Areas, Princeton: 1960, S. 536 ff.

11 G.A.AlmondlJ.S. Coleman, Anm. 10, S. 538. 
correlated with the level of communications, economic development, education and urbanization." (Political Development ist als Entwicklung zum angloamerikanischen politischen System zu verstehen; allerdings gibt er die Möglichkeit politischer Über- oder Unterentwicklung $\mathrm{zu}) .13$

Neubauer 14 macht zwar methodische Einwände, stimmt aber "in gross terms" Cutright zu; reiche Länder seien allerdings weniger stark für Demokratie disponiert als arme zu NichtDemokratie, was insbesondere durch die kommunistische Welt bedingt sei.

Um schließlich einige neuere Autoren zu zitieren: Bollen 15 kommt in seiner Arbeit über die Zusammenhänge zwischen der Position eines Landes im "Weltsystem, Dependenz und Demokratie" zu dem Schluß, "(that) economic development has a significant, positive effect on political democracy"; freilich werde beides - direkt oder indirekt - durch den peripheren Status eines Landes im Weltsystem beeinträchtigt. 16 Huntington17 schließlich stellt 1984 fest (nach einem Forschungsüberblick): "The correlation between wealth and democracy is thus fairly strong." 18

Zusammenfassend: Ältere Forschungsansätze konstatieren auf der Basis teilweise recht sophistizierter Rechnungen und Uberlegungen einen Zusammenhang zwischen Wohlstand und Freiheit/Demokratie. "Zusammenhang" heißt meist "Kausalität", die Kausalitätsrichtung läuft von Wirtschaft zur Politik. Das gilt ohne weiteres für Entwicklung von Armut zu Reichtum: Die Zeitpunktkorrelation wird also ohne methodische Skrupel in einen Entwicklungspfad umgedeutet. Reichtum produziert demnach Demokratie oder ist doch zumindest eine Voraussetzung dafür. Hiergegen können jedoch gravierende methodische Einwände erhoben werden.

12 P. Cutright, National Political Development: Measurement and Analysis, in: American Sociological Review, 28/1963, S. 253-264; hier: S. 253.

13 P. Cutright, Anm. 12, S. 264.

14 D.E. Neubauer, Some Conditions of Democracy, in: The American Political Science Review, 4/1967, S. $1002-1009$.

15 K.A. Bollen, World System Position, Dependency and Democracy: The Cross-National Evidence, in: American Sociological Review, 48/1983, S.468-479.

16 K.A. Bollen, Anm. 15, S.477.

17 S.P. Huntingtion, Will More Countries Become Democratic?, in: Political Science Quarterly, 2/1984, S. 193-218; hier: S. 199.

18 Allerdings spricht er nicht von einer simplen Kausalität vom ersten zum zweiten; die gleich vorzutragende Kritik trifft Huntington insoweit nicht. 


\section{Methodische Einwände ${ }^{19}$}

a) Korrelationen, so lernt man im Proseminar, bedeuten einen mathematischen, nicht notwendig einen sachlogischen Zusammenhang. Ohne es im einzelnen überprüft zu haben, möchte ich vermuten, daß die Korrelation von Klima- und Demokratieindizes vermutlich einen Zusammenhang von gemäßigtem Klima und freiheitlich-demokratischer Verfassung ergäbe. Der Schluß, ein bestimmtes Klima bewirke eine bestimmte Staatsform, wäre indessen kühn. Daß die ermittelten Zusammenhänge auf einer solchen Nonsenskorrelation beruhen, ist allerdings unwahrscheinlich; die Modemisierungstheoretiker haben durchaus sachlogische Plausibilitäten (Mittelklasse, Kommunikation, Empathie, Erziehungswesen) als Zwischenglieder (oder Cluster) angeführt.

b) Beide Reihen (Demokratie und Reichtum) könnten von einer dritten Reihe (oder von einem dritten Faktor) abhängen, sich wechselseitig oder einseitig, aber nicht direkt beeinflussen. Beispiele: Protestantisch-kalvinistische Ethik führt Kapitalismus herauf und gleichzeitig, via Betonung religiös-individualistischen Freiheitsstrebens, geht ein Druck auf Liberalisierung des politischen Systems (Demokratie) aus. Oder. die wissenschaftlich-technische Revolution produziert das ungeheure Wachstum der Produktivkräfte und zugleich eine gesellschaftliche Entwicklung in Richtung Demokratie.

c) Die ungewichtete Länderanalyse ist methodisch streng genommen unzulässig. 20 Kleine und große Länder werden unterschiedslos in einen Topf geworfen, z. B. schlägt das undemokratische Schwarzafrika, obwohl es weit weniger Einwohner hat, mit 45 Staaten viel stärker durch als das annähernd demokratische Indien, - oder anders: hätte der Panafrikanismus Erfolg gehabt, dann ginge Afrika eben nur mit einem statt mit etwa 45 Wertepaaren in die Rechnung ein!

d) Selbst wenn (welche Art von?) Kausalität vorläge, wäre deren Richtung zunächst unklar: Vielleicht produziert Demokratie Wohlstand (statt umgekehrt). Jedenfalls ist es sinnvoll und geschieht auch, die Frage nach den (auch ökonomischen) Leistungen verschiedener Regimetypen zu stellen. Die Antwort wird bezeichnenderweise häufig auf der Basis des

gleichen statistischen Materials versucht, ohne daß die Verschiebung der Fragestellung (bzw., vom ersten Ansatz her gesehen, die methodische Ungereimtheit) irgendwie thematisiert würde.

19 Z.T. unter Rückgriff auf D.A. Rustow, Transitions to Democracy. Toward a Dynamic Model, in: Comparative Politics, 4/1970, S. 337-363; hier: S. 341 ff.; und S.P. Huntington, Anm. 17, S. 199.

20 Herm Kollegen Heiner Treinen von der Ruhr-Universität Bochum danke ich für eine mündliche Bestätigung dieser Behauptung. 
e) Schließlich wäre die Umdeutung Zeitpunkt- in Zeitreihenanalyse zu hinterfragen ${ }^{21}$ : Gibt eine Zeitpunktkorrelation, wie leichthin angenommen, einen Entwicklungspfad wieder? Bangla Desh links unten, Schweiz rechts oben, andere Länder dazwischen: kann ich die Schweiz 1990 zum Bangla Desh 2050 - oder wann immer - erklären? Ist überhaupt aus Korrelationen armer/undemokratischer und reicher/demokratischer Länder auf einen Entwicklungspfad zu schließen? Und wenn: wäre die Annahme einer Wiederholung nicht Ethnozentrismus, Übertragung europäisch-amerikanischer Entwicklung auf die Dritte Welt? Damit kommen wir zu neueren Analysen, die diesen Fehler vermeiden.

\section{Moderne Analysen: Zeitreihenkorrelationen Demokratie-Wohlstand}

Behauptung: Wohlstand führt zu Demokratie.

Nochmals zum systematischen Zusammenhang22: Wenn die von den Modemisierungstheoretikem implizit oder explizit vorgenommene Umdeutung der statistisch feststellbaren Korrelation Wohlstand/Armut mit Demokratie zum Zeitpunkt $x$ in einen Entwicklungspfad richtig wäre23, dann gälte, ceteris paribus, daß einzelne Länder umso demokratischer 24 werden müßten, je wohlhabender sie würden. Zudem müßte die Wiederholung der Regressionsanalyse zu verschiedenen Zeitpunkten (für viele Länder) jeweils konsistente Ergebnisse erbringen. Schließlich wäre die Form der Regressionsfunktion - falls nachweisbar genauer zu bestimmen. Die neueste (und gründlichste) Studie hierzu ist die von Arat.25 Er geht in drei Schritten vor:

1. Schritt: Entwicklung theoretisch möglicher Regressions-Funktionen. Offenbar gibt es grundsätzlich drei mögliche Kurven. Erstens: Linearer Zusammenhang zwischen Indizes für Demokratie und wirtschaftliche Entwicklung, wobei dieser Zusammenhang, wie auch in den folgenden Fällen, positiv und negativ sein kann.26 Zweitens: Gleichsinniger (bzw. gegenläufiger) Zusammenhang mit abnehmenden Steigungsraten bis zu einem Sättigungs-

21 D.A. Rustow, Anm. 19, S. 341, spricht von "simple equation of function and genesis", d. h. die Funktion prosperierender Wirtschaft zur Stützung funktionierender Demokratie wird in genetischen Zusammenhang uminterpretiert.

22 Nach ZF. Arat, Democracy and Economic Development. Modemization Theory Revisited, in: Comparative Politics, 10/1988, S. 21-37; hier: S. 23 f.

23 Und, selbstverständlich, der angenommene kausale Zusammenhang

24 Hier wie im gesamten Aufsatz wird - in Übereinstimmung mit der referierten Literatur - Demokratie nicht als ein Alles-oder-Nichts-Konzept begriffen. Für die Rechnungen legen die verschiedenen Autoren im einzelnen unterschiedliche, im Grundansatz aber übereinstimmende zusammengesetzte Indizes zugrunde, die etwa verschiedene Grade der Freiheit von Wahlen, der Betätigung von polit. Parteien usw. messen.

25 Z.F. Arat, Anm. 22.

26 Das hieße also: je reicher ein Land ist, desto demokratischer wäre es auch, bzw. umgekehrt, je reicher, desto undemokratischer. 
punkt, von dem an einer wachsenden Wirtschaft gleichbleibende Indizes für das Demokratieniveau entsprechen. Schließlich ein Kurvenpaar, das dem zweiten im linken Teil entspricht, bei dem aber der Sättigungspunkt zum Maximum (bzw. Minimum) wird: Jenseits geht das erreichte Demokratieniveau mit wachsendem Wohlstand wieder zurück (bzw. umgekehrt). - Offensichtlich besteht auch die Möglichkeit, daß überhaupt keine systematische Beziehung zwischen Wirtschafts- und Demokratieindizes besteht, $d$. h. keine Regressionsfunktion ermittelt werden kann.

2. Schritt: Eine Longitudinalanalyse (Zeitreihenkorrelation), d. h. einhundertzwanzig Länder werden für 1948-1977 als separate Reihen behandelt und ihr wirtschaftlicher Entwicklungsstand mit einem komplexen Demokratieindikator korreliert und jeweils festgestellt, welche der möglichen Funktionen am besten auf die Daten paßt.

3. Schritt: Interpretation der Daten. "If the evolutionary thesis suggested by the modernization theorists is to hold, most of the "developing countries" should appear in the positivelinear category, and most of the "developed" countries should appear in the No-relationship category. However only a few countries fit the models suggested by modernization theory: out of 120 countries only eight (even though all can be considered as developing countries) experience increasing levels of democracy with increasing levels of economic development, and the developed countries with the rest of the developing countries are spread in the other categories, each of which suggests a different pattern of relationship.

On the basis of these findings it can be concluded that increasing levels of economic development do not necessarily lead to higher levels of democracy, even for the less developed countries. Such a relationship, which has been observed through the study of cross-national data, suggests only that at a given time point the countries with more democratic political systems happen to be the ones which are economically more developed. As Rustow emphasized in his critique of the 'Lipset-Cutright genre', correlation is not the same as causation.

Developing countries, on the other hand, do not display a linear relationship, but rather more complex pattems or no systematic relationship at all. In fact, most of these countries, especially the ones which are located in the middle of the development axis, experience higher levels of instability, a continuous back and forth shift, on the scale of democracy." 27

27 Z.F. Arat, Anm. 22, S. 30.- Demgegenüber ergibt eine neuere Analyse von J.B. Londregan und K.T. Poole, Poverty, The Coup Trap, and the Seizure of Executive Power, in: World Politics, 2/1990, S. 151-183; hier: S. $177 \mathrm{f}$., "the probability that a govemment is overthrown by a coup d'état is substantially influenced by the rate of economic growth. The negative association between successful coups and income is more pronounced than any of the interrelationships among the political variables in our data ... even authoritarian govemments have powerful incentives to 
Insgesamt ergibt sich: Demokratie ist nicht eine Art Leiter, die Länder mit wachsendem Wohlstand immer weiter hinaufsteigen.28

Notieren wir abschließend zwei Dinge:

- Die Ergebnisse Arats widersprechen zumindest nicht den vorsichtigen Formulierungen Lijpharts. $29 \mathrm{Er}$ meint z. B. "correlation, which is merely statistical, is far from perfect, and has many notable exceptions. To the extent that it indicates a causal relationship, it may well be that democracy rather than economic development is the cause."

- Die Befunde von Arat widersprechen auch nicht (notwendig) den Behauptungen Guillermo O'Donnells ${ }^{30}$, daß mit zunehmendem lateinamerikanischen Modemisierungsstand keine Verbindung ("association") mit politischer Demokratie bestehe.

\section{Behauptung: Demokratie führt zu Wohlstand}

Wenn Demokratie Wohlstand nicht zur Voraussetzung hat, könnte sie jedoch, umgekehrt, ihrerseits Wohlstand hervorbringen. Dieser Frage- oder allgemeiner, den wirtschaftlichen Erfolgen verschiedener Regimetypen - wenden wir uns jetzt zu.

In der Frühzeit der Entwicklungshilfe und Unabhängigkeit der Kolonien ist über das Problem, welche Regierungsform am schnellsten den ersehnten wirtschaftlichen Aufschwung herbeiführen werde, viel spekuliert worden. Das Ergebnis war oft, dieser setze den "starken Mann", autoritäre Regime voraus, so daß ein Zielkonflikt zwischen Demokratie und wirtschaftlicher Entwicklung bestehe. Die Begründung lautete etwa, Demokratie mache Konsumeinschränkung, damit Erspamis, damit Investition, damit Wachstum schwierig, vor allem in sehr armen Entwicklungsländern nahe dem Subsistenzniveau. 31 Der

promote economic growth ... because failure to deliver adequate economic performance may lead to their own downfall."

$28 \mathrm{Zu}$ den südeuropäischen "postautoritären Demokratisierungsprozessen", die "nach einer langanhaltenden Phase wirtschaftlichen Aufschwungs" einsetzen, siehe P.A. Kraus, Elemente einer Theorie postautoritärer Demokratisierungsprozesse im süd-europäischen Kontext, in: Politische Viertel jahresschrift, 2/1990, S. 191-213. Gemeint sind allerdings Länder wie Portugal, Spanien, Griechenland in den siebziger Jahren, nicht die Balkanländer des Jahres 1990!

29 A. Lijphart, Democracy in Plural Societies. A Comparative Exploration, New Haven/London: 1977 , S. $230 \mathrm{f}$.

30 G.A. O'Donnell, Modemization and Bureaucratic-Authoritarianism. Studies in South American Politics, Berkeley: 1973, S. 3-15; S. 113 f.

31 S. Andreski, Parasitism and Subversion. The Case of Latin America, New York: 1969, S. 266, (zit. nach $E$. Weede, The Inpact of Democracy on Economic Growth: Some Evidence from CrossNational Analysis, in: Kyklos, 36/1983 (Fasc. 1), S. 21-39; hier: S. 21): "Democracy is compatible with rapid economic growth only in countries which already have enough resources to make heavy 
starke Mann wurde (und wird zum Teil) gefordert; wilde Konjekturen aufgestellt, etwa zu Lateinamerika: Auslandskapital stehe - natürlich - nur bei "stabilen", d. h. undemokratischen, Verhältnissen zur Verfügung, Regimerepression und Wirtschaftswachstum seien die Folge.32 Die entsprechenden Stimmen werden neuerdings leiser, sind aber nicht ausgestorben. Beispiele: Mugyeny (1988)33: "The likelihood of the developing countries enjoying both democracy and development at the same time is limited. They must decide which of the two is more urgent ... Our proposition is that democracy ... comes in small installments behind development ... the sequence is straightforward. Development first, democracy second."

Cohen34: "... third world countries are bound to run into major obstacles that can be overcome only by the implementation of austere policies requiring authoritarian forms of govemment." "... if one believes that relatively poor countries should improve their growth rates at any cost, half a percent might justify a temporary suspension of democratic rights". Schließlich, zum Zusammenhang von Stabilität und Wirtschaftsentwicklung, Olson35: "... over the long term Olson asserts that political stability 36 can be economically dysfunctional and cause growth to decelerate." Solche und ähnliche Behauptungen finden sich bei zahlreichen anderen Autoren.

investment a relatively painless process. There is no case of a democratic govemment breaking through a vicious circle of misery and parasitism."; R. Löwenthal, Staatsfunktionen und Staatsform in den Entwicklungsländem, in: R. Löwenthal (Hrsg.), Die Demokratie im Wandel der Gesellschaft, Berlin: 1963, S. 187 (zit. nach D. Berg-Schlosser, Leistungen und Fehlleistungen politischer Systeme der Dritten Welt als Kriterium der Entwicklungspolitik, in: Konjunturpolitik, 1+2/1985, S. 79-114; hier: S. 79): "Jeder Grad an Freiheit wird mit etwas Verlangsamung der Entwicklung, jeder Grad an Beschleunigung mit etwas Verlust an Freiheit bezahlt. Das ist in der Natur des Prozesses unvermeidlich."

32 J. Sheahan, Market-Oriented Economic Policies and Political Repression in Latin America, in: Economic Development and Cultural Change, 28/1980, S. 267-291; hier: S. 290; G.A. O'Donnell, Reflections on The Pattems of Change in the Bureaucratic-Authoritarian State, in: Latin America Research Review, 13-1/1978, S. 3-38; (zit. nach D. Collier (Hrsg.), The New Authoritarianism in Latin America, Princeton 1979, S. 292.): Der Bureaucratic-Authoritarian-State "is, first and foremost, guarantor and organizer of the domination exercised through a class structure subordinated to the upper fractions of a highly oligopolized and transnationalized bourgeoisie".

33 Dozent in Nairobi; M. Mugyenyi, Development First, Democracy Second. A Comment on Minimalist Democracy, in: W.O. Oyugi et al. (Hrsg.), Democratic Theory and Practice in Africa, Portsmouth/London: 1988, S. 179.

$34 Y$. Cohen, The Impact of Bureaucratic-Authoritarian Rule on Economic Growth, in: Comparative Political Studies, 1/1985, S. 123-136; hier: S. 125; S. 134.

35 M. Olson, The Rise and Decline of Nations: Economic growth, Stagflation and Social Rigidities, New Haven: 1982; hier referiert nach A.A. Goldsmith, Does Political Stability Hinder Economic Development? Mancur Olson`s Theory and the Third World, in: Comparative Politics, 7/1987, S. 471-480; hier: S. 472.

36 Sicherlich mit Demokratie nicht gleichzusetzen, aber eine notwendige Bedingung! 
Früh gibt es indessen wamende Stimmen und neuerdings präzise Untersuchungen, die Zweifel an dem behaupteten Zusammenhang aufkommen lassen. Bereits 1966 (also zur Zeit der "political-development"-Literatur) argumentiert Lucian W. Pye37, "it can be argued that at present in most situations rapid economic growth is more likely to be stimulated by a reduction in authoritarian practices and an increase in popular participation in the nation-building process (was sicher der Demokratisierung gleichzusetzen ist!). It should be remembered that the history of most backward societies is that of authoritarian rule".

In einer Serie von drei Artikeln zum gleichen Thema kommt Erich Weede38 unter Verwendung sophistizierter Berechnungen und umfangreichen Materials39 zwar prima vista zu dem Schluß, daß Demokratie negative Wachstumseffekte mit sich bringe. Nimmt man indessen notwendige Korrekturen vor (betrachtet z. B. nur Entwicklungsländer und kontrolliert statistisch die staatliche Einmischung in das Wirtschaftsleben 40 oder berücksichtigt das Niveau wirtschaftlicher Entwicklung, Investitionen, Schulbesuchsquoten, Militärgröße, Preisverzerrungen, "Urban bias")41, dann fällt die scheinbare ökonomische Überlegenheit von autoritären Regimen in sich zusammen. "Nicht Demokratie per se, sondern die Kombination von Demokratie und starker staatlicher Einmischung in das Wirtschaftsleben schadet den Wachstumschancen von Gesellschaften." 42 "This paper does not support the argument in favor of the existence of a simple trade-off between democracy and growth, between liberty and bread, in LDC's. Instead, it argues that a second-order tradeoff exists, and it implies this advice to LDC's and their politicians: if you want to avoid a trade-off between democracy and growth, you should not maximize government revenues, nor should you interfere too much with the economy." 43 "This cross-national study could not support the proposition that repressive regimes achieve better economic growth rates than democratic ones ... the two blessings of democracy and growth appear to be available simultaneously."44 Andere Autoren, die zum gleichen Ergebnis kommen, seien in Kürze

37 L.W. Pye, Aspects of Political Development, Boston/Toronto: 1966, S. 73.

38 E. Weede, Anm. 31; E. Weede, Political Democracy, State Strength and Economic Growth in LDCs: A Cross-National Analysis, in: Review of Intemational Studies, 10/1984, S. 297-312; und E. Weede, Price Distortion, Democracy or Regime Repressiveness and Economic Growth Rates among LDCs, 1973-1983, in: Pacific Focus, 2/1988, S. 23-39.

39 E. Weede, Anm. 31, z. B. 90 Länder für den Zeitraum 1960-1979.

40 so $E$. Weede, Anm. 31 und Anm. 38/2.

41 E. Weede, Anm. 38/3.

42 E. Weede, Anm. 31, S. 39.

43 E. Weede, Anm. 38/2, S. 309.

44 E. Weede, Anm. 38/3, S. 36 f.; E. Weede nimmt diese Zusammenhänge unter Bezug auf frühere Arbeiten in seinem jüngsten Buch $(E$. Weede, Wirtschaft, Staat und Gesellschaft. Zur Soziologie der kapitalistischen Marktwirtschaft und der Demokratie, Tübingen: 1990, S. 181 f.) wieder auf: "Demnach möchte ich ... nicht behaupten, daß Demokratie per se Wirtschaftswachstum und Ent- 
genannt: Berg-Schlosser ${ }^{45}$, in seiner englischsprachigen Zusammenfassung: "In contrast to what is often alleged, only polyarchies and - to a somewhat lesser extent - the semicompetitive systems demonstrate both satisfactory rates of economic development and a basic observance of certain fundamental human rights standards."

Ansprenger46: "Eine Afrika angemessene Form politischer Partizipation des Volkes könnte nach meiner Überzeugung auch Wirtschaftskräfte freisetzen, die Afrika eine Bewältigung seiner Krise erlauben würde."

Goldsmith47: "Analysis of variance does not indicate a significant difference in growth trends: countries that had either large increases or large decreases in political instability had comparable economic performances."

Schließlich Remmer48, in einer Studie über die Gefährdung demokratischer Konsolidierung in Latein-Amerika durch die Schuldenkrise: "... no statistically significant differences emerge between democratic and authoritarian regimes, or between new democracies and more established regimes. The findings suggest that the conventional wisdom about democracy and economic crisis exaggerates the relationship between political regime characteristics and policy choice, and fundamentally misconstrues the strengths and weaknesses of liberal democratic forms of governance." 49

Fassen wir zusammen: Alle Belege, die - mehr oder weniger leichthändig - eine ökonomische Úberlegenheit autoritärer Systeme gegenüber liberalen Demokratien behaupteten, sind im Lichte neuerer Forschungen als fragwürdig anzusehen. Für außenpolitische Zwecke ist letzte Gewißheit aber auch gar nicht nötig: Bedenkt man die menschlichen Vorzüge der Demokratie, dann kann die Wahl nicht schwer fallen, selbst wenn die ökonomische Úberlegenheit dieser Staatsform nur vermutet, aber bisher nicht bewiesen werden kann. Die

wicklung verlangsamt. Bei angemessener Spezifikation der Regressionsgleichungen ... läßt sich kein allgemeiner Zusammenhang von Demokratie ... und ... Wachstum aufzeigen."

45 D. Berg-Schlosser, Anm. 31, S. 101.

46 F. Ansprenger, Versagen und Leistung des unabhängigen Afrika, in: Aus Politik und Zeitgeschichte, 36/1986, S. 3-15; hier: S. 15.

47 A.A. Goldsmith, Anm. 35, S. 477.

48 Karen L. Remmer, Democracy and Economic Crises: The Latin American Experience, in: World Politics, 3/1990, S. 315-335 (zitiert nach dem Abstract, ohne Paginierung vor dem Aufsatz).

49 Siehe auch G. Hischier, Politische Regimes in Entwicklungsländem. Eine international vergleichende Typologie, Frankfurt am Main: 1987, S. 184: "Im Rahmen des von uns verwendeten Datensatzes ... ist die durchschnittliche ökonomische Wachstumsrate der demokratischen Regime ... in der Tat signifikant höher als die der anderen Regimetypen ...". 
Empfehlung zu mehr Demokratie in der Dritten Welt kann jedenfalls nicht mit dem zynischen Wort: "Erst kommt das Fressen, dann die Moral" abgetan werden!50

\section{Politische Folgerungen 51}

Halten wir nochmals als Hauptergebnis der Untersuchung fest:

1. Es gibt keinerlei überzeugende Beweise für die Behauptung, Armut für sich genommen verhindere die Einführung oder Aufrechterhaltung demokratischer Systeme;

2. Ebensowenig besteht eine Alternative zwischen Freiheit und Wohlstand. Für Länder der Dritten Welt gilt mindestens, daß marktwirtschaftliche Wirtschaftsordnungen mit einer

50 Wie in der Einleitung angekündigt, in Kurzform einige Hinweise zum Zusammenhang von Einkommensverteilung und Demokratie. Wiederum müssen zwei Unterfragen unterschieden werden: 1) Setzt Demokratie (relative) Einkommensgleichheit voraus? 2) Führt sie diese herbei? $\mathrm{Zu} \mathrm{1}$ ): Von Aristoteles (Politeia) angefangen haben zahlreiche Theoretiker die Frage bejaht, in jüngerer Zeit etwa Lipset (S.M. Lipset, Anm. 5, S.75; Anm. 9, S. 59 ff.) oder Huntington (S.P. Huntington, Anm. 17, S. 199: "... democracy is only possible if the majority is a relatively satisfied middle class, and not an impoverished majority confronting an inordinately wealthy oligarchy".). Die neueste (auch empirische) Forschung ist widersprüchlich; eine demokratiebeeinträchtigende Wirkung der Einkommensungleichheit vemeinen etwa Bollen/Jackman (KA. Bollen/R.W. Jackman, Political Democracy and The Size Distribution of Income, in: American Sociological Review, 50/1985, S. 438-457; hier: S. 450) und E. Weede (E. Weede, Income Inequality and Political Violence Reconsidered, in: American Sociological Review, 51/1986, S. 438-445; E. Weede, Democracy and Income Inequality Reconsidered, in: American Sociological Review, 54/1989, S. 865-868), dieser in seiner Kontroverse mit Muller (EN. Muller, Income Inequality, Regime Repressiveness, and Political Violence, in: American Sociological Review, 50/1985, S. 47-61; hier: S. 52 ff.; EN. Muller, Democracy, Economic Development, and Income Inequality, in: American Sociological Review, 53/1988, S. 50-68), der sie bejaht. Weede neuerdings (E. Weede, Anm. 44/2, S. 182/Fußnote 1), "Alle Befunde zum Zusammenhang zwischen Demokratie und Ungleichheit sollten mit Vorsicht interpretiert werden. Die Qualität der Ungleichheitsdaten läßt zu wünschen übrig. Die Resultate hängen manchmal davon ab, welchen Ungleichheitsdatensatz man zugrunde legt." Zu 2): Demokratie und ihr Einfluß auf die Einkommensverteilung: Wiederum zwei einander widersprechende Befunde: Bollen/Jackman (K.A. Bollen/R.W. Jackman, s.o., passim) finden keinerlei sinnvollen Zusammenhang zwischen beiden (und theoretisieren, warum Demokratie Einkommensgleichheit offenbar nicht vergrößert). Für E.N. Muller ergibt sich: "Continuous and qualitative measures of years of democratic experience are overestimated to have a significant negative impact on income inequality independent of economic development and other control variables for a sample of 55 countries." (EN. Muller, s.o. 1988, S. 50). "These results strongly support the argument that the egalitarian influence of democracy is a gradual process, resulting from a country's accumulated years of democratic experience ... ." (EN. Muller, s.o. 1988, S. 57). Weede's Kritik greift auch hier.

51 Hierzu auch Berg-Schlosser, Anm. 31, S. 94-100. 
soliden Wirtschaftspolitik keine schlechteren Resultate als planwirtschaftliche Versuche mit sich gebracht haben. 52

Für die Industrieländer des (ehemaligen) Ostblocks ist der ökonomische Scherbenhaufen zu offensichtlich, um langer Kommentare zu bedürfen. Bedenkt man nun die von den Theoretikem der sozialen Marktwirtschaft und zahlreichen anderen liberalen Ökonomen angenommene Kongruenz der Ordnungen (hier also der politischen und der wirtschaftlichen Ordnung), dann gilt mindestens mittel- bis langfristig, daß eine marktwirtschaftliche Wirtschaftsordnung sich nicht mit autoritärer oder diktatorischer politischer Ordnung verträgt.

Es folgt für Entwicklungsländer:

Alle Behauptungen, die Einführung und Beibehaltung demokratischer Systeme scheiterten an der Armut eines Landes bzw. deren Uberwindung setze autoritäre Herrschaftsformen voraus, sind im Lichte der neueren Forschung unhaltbar. Soweit derartige Behauptungen von Wissenschaftlem verbreitet werden, ist mangelnde Beschäftigung mit dem Forschungsstand anzunehmen. Äußern sich gar autoritäre Politiker in diesem Sinne, ist ein argumentum ad hominem zu vermuten: $\mathrm{Zu}$ Unrecht behauptete Sachzwänge verdeckten und "entschuldigten" dann eigene Herrschaftsinteressen.

Für die Außenpolitik der Industrieländer ergibt sich:

1. Pessimismus hinsichtlich der grundsätzlich gegebenen Möglichkeit der Demokratie auch in armen Ländern wäre unangebracht. Die Werbung für das eigene Modell nicht nur, weil es menschliches Zusammenleben in humaner und freiheitlicher Weise ermöglicht, sondern auch, weil es ökonomisch mindestens ebenso leistungsfähig ist wie andere Modelle, kollidiert jedenfalls nicht mit dem Stand ökonomischer Unterentwicklung. Resignation (oder Abwarten) bis zum Zeitpunkt ökonomischen Wohlstandes der heutigen Entwicklungsländer wäre jedenfalls die falsche Politik.

2. Wenn die Altemative Freiheit und Wohlstand nicht besteht, wären solche Behauptungen auch (und gerade) dann nicht zu akzeptieren, wenn sie von Diktatoren vorgebracht werden. Die Aufkündigung der entwicklungspolitischen Kooperation 53 und die Unterstützung von Bestrebungen zur Demokratisierung wären dann nicht nur im Interesse des deutschen

52 J.H. Wolff, Planung in Entwicklungsländern. Eine Bilanz aus politik- und verwaltungswissenschaflticher Sicht, Berlin: 1977.

53 Man zögert, auch die humanitäre Hilfe, die nicht der Entwicklungshilfe zuzurechnen ist, miteinzuschließen. Indessen: Bedeutet sie nicht in vielen Fällen eine Entlastung und Verminderung des Drucks auf Politikänderung gerade jener Potentaten, die die Zustände, die Hilfe nötig machen, erst hervorgebracht haben (so schon P.T. Bauer vor Jahrzehnten: P.T. Bauer, Dissent on Development, London: 1971; P.T. Bauer, Reality and Rhetoric, London: 1984; P.T. Bauer/B.S. Yamey, Markets, Market Control and Marketing Reform, London 1968)? Ähnlich könnte für den Bereich der Nichtregierungsorganisationen und deren Entwicklungszusammenarbeit argumentiert werden! 
Steuerzahlers, sondem vor allem des betroffenen Landes selbst: Im Erfolgsfalle wäre dessen politisches System nicht nur ökonomisch effizienter, sondern auch freiheitlicher und damit humaner. Die Abminderung der Ost-West-Spannung ließe Erpressungsmanöver von autoritären Regimen, sich dem anderen Lager anzuschließen (denen nachzugeben sicherlich nie eine durchdachte Außenpolitik war), um so weniger glaubwürdig erscheinen.

Westlichen Demokratien wäre eine entschiedenere Förderung der Demokratie in Entwicklungsländern zu empfehlen. Sie können dies umso leichter tun, als der Vorteil eindeutig auch bei den Drittweltländern selbst läge. 


\title{
Democracy, Poverty and Development: A Review
}

\author{
By Jürgen $H$. Wolff
}

The article centers on two main themes:

1. A review of the old question of poverty of a developing country and its political system are systematically related;

2. whether economic development in the developing world rests necessarily on authoritarian forms of government.

As to the first question, simply correlating indicators of wealth and of democracy, a strong correlation results. However, should a cause-and-effect-relation exist, it is unclear what is the cause and what the effect: Are developing countries authoritarian because they are poor or are they poor because they are authoritarian? The strong correlation disappears if replaced by a time-series-analysis (following Arat): No clear relation between development of economic and development of democracy indicators could be found.

As to the second question, it can at least be shown that democratic forms of government in the Third World do not result in worse economic performance than authoritarian ones. Given the many advantages of democratic forms of government, e.g. in the human rights sphere, developing countries ought to introduce or reinforce democratic systems also if they wish to accelerate their economic development. Furthermore, Western foreign and development policy should insist on such a procedure: the objection that economic development is possible only with authoritarian government simply is not valid!

\section{The Organization of the Islamic Conference}

\section{By Mark Zimdars}

The Organization of the Islamic Conference (OIC), with 45 member states the largest intergovernmental organization outside the UN framework, is still seeking its place in the Muslim world after 20 years of existence.

The article describes the historical development which led to the foundation of the OIC and examines its structure as well as its work in political, economic and cultural areas.

Special attention is given to the influence of Islam on this organization and vice versa as Islam is its cohesive factor. For this reason, the attitude of e.g. Saudi Arabia and Pakistan towards the OIC from the viewpoint of Islam are analysed.

The political, economic and cultural differences of its member states, the endless tensions among them and serious financial difficulties have contributed to the very limited success of the OIC and its numerous specialised committees, subsidiary organisations and other affiliated institutions. 